\title{
Potential for Timberline Advance in Northern Finland, as Revealed by Monitoring during 1983-99
}

\author{
V. JUNTUNEN, ${ }^{1}$ S. NEUVONEN,${ }^{2}$ Y. NOROKORPI ${ }^{3}$ and T. TASANEN ${ }^{4}$
}

(Received 26 February 2001; accepted in revised form 23 January 2002)

\begin{abstract}
Seedling density, tree density and basal area of Scots pine (Pinus sylvestris L.) and Norway spruce (Picea abies (L.) Karst) were monitored and compared in the timberline areas of northern Finland during the period 1983-99. Rows of 9-12 circular plots were established at 13 localities in four regions: pine-dominated northern and southern regions and spruce-dominated western and eastern regions. Temporal changes were monitored in three altitudinal zones: in the forest, at the coniferous timberline (where forest canopy closure ceases), and at the tree line (where coniferous trees higher than $2 \mathrm{~m}$ cease). Pine seedling densities decreased abruptly in the southern region, especially at the timberline, but increased slightly in the northern region. The zone $\cdot$ region $\cdot$ change interaction was significant. The change in spruce seedling densities was small in the forest and timberline zones, but the densities more than doubled at the tree line. Tree density and basal area increased in all the zones and regions. New regeneration and tree establishment during the study period indicate a potential for the tree line to advance. However, there was great heterogeneity in regeneration and seedling establishment among the localities.
\end{abstract}

Key words: climate change, climatic variation, regeneration, Pinus sylvestris, Picea abies, seedling density, tree density, basal area, timberline, tree line

RÉSUMÉ. La densité des semis, la densité des arbres et la surface terrière du pin sylvestre (Pinus sylvestris L.) et de l'épinette de Norvège (Picea abies [L.] Karst) ont fait l'objet d'une étude et d'une comparaison dans des zones situées à la limite de la forêt de la Finlande septentrionale durant la période allant de 1983 à 1999. Des rangées de 9 à 12 parcelles circulaires ont été créées à 13 sites répartis dans 4 zones: les régions septentrionale et méridionale où dominait le pin sylvestre, et les régions occidentale et orientale où dominait l'épinette de Norvège. On a mesuré les changements temporels dans 3 zones d'altitude différente: dans la forêt, à la limite de la forêt de conifères (là où cesse la fermeture du couvert forestier), et à la limite des arbres (là où cessent les conifères de plus de $2 \mathrm{~m}$ de haut). La densité de semis du pin sylvestre diminuait brusquement dans la région méridionale, en particulier à la limite de la forêt, mais elle augmentait légèrement dans la région septentrionale. L'interaction zone-régionchangement était significative. Le changement dans la densité de semis de l'épinette de Norvège était faible dans la forêt ellemême et dans les zones de la limite de la forêt, mais la densité avait plus que doublé à la limite des arbres. La densité des arbres et la surface terrière augmentaient dans toutes les zones et les régions. Une nouvelle régénération et un nouvel établissement d'arbres durant la période d'étude révèlent que la limite des arbres pourrait progresser. Il y avait toutefois une grande hétérogénéité dans la régénération et dans l'établissement des semis parmi les divers sites.

Mots clés: changement climatique, variation climatique, régénération, Pinus sylvestris, Picea abies, densité des semis, densité des arbres, surface terrière, limite de la forêt, limite des arbres

Traduit pour la revue Arctic par Nésida Loyer.

\section{INTRODUCTION}

Since forests and trees close to the timberline are sensitive to climate and climatic stresses, they are ideal study objects for monitoring the ecological consequences of regional and global climate change. However, the effects of earlier climatic conditions often do not become evident for a long time; that is, the time needed for both regeneration and mortality processes to be realized creates considerable "inertia" in these ecosystems (Kullman, 1981; Brubaker, 1986;
Ritchie, 1986). The density, growth, and altitudinal limit of young seedlings show a relatively rapid response to climatic change (Kellomäki et al., 1997). On the other hand, the trees and the position of the timberline react more slowly to such changes (Payette and Filion, 1984). Climate change may also alter the tree species composition near the timberline, because different tree species react in different ways to climatic variation (Brubaker, 1986; Kellomäki et al., 1992).

Some tree species may benefit considerably from increased temperatures. The impact will be seen primarily as

\footnotetext{
${ }^{1}$ Kolari Research Station, The Finnish Forest Research Institute, FIN-95900 Kolari, Finland; vesa.juntunen@metla.fi

${ }^{2}$ Kevo Subarctic Research Institute, University of Turku, FIN-20014 Turku, Finland; sepne@utu.fi

${ }^{3}$ Rovaniemi Research Station, The Finnish Forest Research Institute, P.O. Box 16, FIN-96301 Rovaniemi, Finland; yrjo.norokorpi@ metla.fi

${ }^{4}$ Tuomarniemi School of Forestry, Seinäjoki Polytechnic, FIN-63700 Ähtäri, Finland; tapani.tasanen@ seamk.fi

(C) The Arctic Institute of North America
} 
an increase in growth and productivity resulting from the prolonged growing season (Junttila and Nilssen, 1993; Beuker, 1994; Fries et al., 1998). At the timberline ecotone, the growing season is expected to change from the present $110-120$ days up to $150-160$ days by 2100 (Kellomäki et al., 1997). The mean annual temperature sum $\left(+5^{\circ} \mathrm{C}\right.$ threshold) is projected to increase by more than 500 degree-days (Fries et al., 1998). This would dramatically affect the maturation of Scots pine (Pinus sylvestris L.) and Norway spruce (Picea abies (L.) Karsten) seeds, thus increasing the frequency of seed years of conifers in the timberline ecotone (Kellomäki et al., 1997).

Some studies, however, suggest that the present tree species are not able to adapt to such drastic increases in temperature. Expected results include catastrophic damage to trees through climatic stress and increased evapotranspiration (Gates, 1990; Ledig and Kitzmiller, 1992; Leemans, 1995; Juday et al., 1997), insect outbreaks (Fleming, 1996; Juday et al., 1997), fungal diseases (Greifenhagen, 1998), and an increase in forest fires (Stocks et al., 1998). Severe frost damage has also been predicted as a consequence of increasing fluctuations in spring temperatures, with a subsequent increase in tree and seedling mortality in the climatically extreme areas especially (Cannell and Smith, 1986; Hänninen, 1991).

Given these controversies over future trends in the timberline areas of northern Europe, baseline empirical data about recent trends are essential to developing models that will predict the responses of forests near the timberline under varying climatic conditions more accurately. In this study, we describe the regional variability in seedling and tree density and basal area in different timberline zones in northern Finland. Changes in these variables were monitored during the period 1983-99.

\section{METHODS}

\section{Study Area and Climate}

In Finnish Lapland, coniferous timberlines occur over an area spanning $400 \mathrm{~km}$ in the south-north direction (Fig. 1). These timberlines vary in nature from the southern, clearly alpine timberlines, which occur on scattered fells in the midst of continuous boreal forest (taiga), to the northern ones, where the pine forests meet the mountain birch forest zone (Hämet-Ahti, 1963). It is difficult to say whether these timberlines are better characterized as alpine or arctic timberlines (cf. Eurola, 1974).

In order to characterize climatic conditions during the growing season, we have used the effective temperature sum expressed in degree-days. Degree-day (d.d.) is a linear temperature sum unit based on daily mean temperature minus the threshold value, $+5^{\circ} \mathrm{C}$. The temperature sum equation is:

$$
\text { d.d. }{ }_{5}=\sum_{n=1}^{n}\left(t_{m}-5\right)
$$

where d.d. ${ }_{5}$ is the accumulated temperature sum, $n$ is the total number of days with a mean temperature higher than the threshold temperature, and $t_{m}$ is the mean temperature of the $n$th day. Temperature sums were calculated for the timberline locations with the program of Ojansuu and Henttonen (1983), which estimates temperature sums for given locations on the basis of Finnish Meteorological Institute data. The program takes into account the altitude of the site, its distance from the sea, and the presence of lakes in the neighborhood.

The mean annual temperature sum during the period 1983-99 was slightly below the 20th century mean (for example, mean temperature sums in Kevo, the northernmost locality, were 608 d.d. during 1900-82 but only 597 d.d. during 1983-99). Three summers, 1988, 1989, and 1997, were slightly warmer than the average, and the other summers were close to the 20th century mean (Fig. 2). During the 20th century, 17 summers were warmer than the warmest summer of the study period. The study period was characterized by low variation between the years, i.e., there were no unusually warm or cold summers, except the summer of 1987, which was markedly colder than the average (Fig. 2). All the winters (except the cold ones in 1987 and 1999) were fairly mild, and the average snow depth in the 1980s and 1990s was slightly thicker than earlier in the century because of increased precipitation, especially during spring (Solantie, 2000).

Four regions were delineated on the basis of predominant tree species and geographical location. The pinedominated areas were divided into a northern and a southern region ( $\mathrm{P}-\mathrm{N}$ and $\mathrm{P}-\mathrm{S})$, and the spruce-dominated areas into a western and an eastern region (S-W and S-E). Each region includes two to four localities, giving a total of 13 localities in northern Finland (Table 1, Fig. 1). All the localities are situated on mineral soil sites, and the site type is dry or semi-dry heath. The regional climate is mostly (sub)continental, with cold winters and relatively warm summers (Tuhkanen, 1980, 1984).

The localities in the P-N region are all situated either in separate enclaves of pine forest to the north of the northern timberline, or on the northern timberline. Mountain birch (Betula pubescens Ehrh. ssp. czerepanovii (Orlova) HämetAhti) is common at the pine timberline and tree line. The pure mountain birch zone is well developed above or to the north of the pine tree line. The climate of the northernmost localities especially is relatively maritime (Kallio et al., 1969; Tuhkanen, 1980). The altitude of the timberline ranges between 180 and $275 \mathrm{~m}$ a.s.l., and the annual mean temperature sum between 581 and 644 d.d. (Table 1). The soils are glacial till derived from the underlying granulite or granitoid gneiss, and they are therefore coarse-textured and relatively infertile (Koljonen et al., 1992).

The localities in the P-S region are situated on fells within the boreal forest zone. Mountain birch is less dominant at the upper elevations than in the northern localities, and the coniferous tree line borders on the scattered mountain birch zone or directly on the fell heath. 


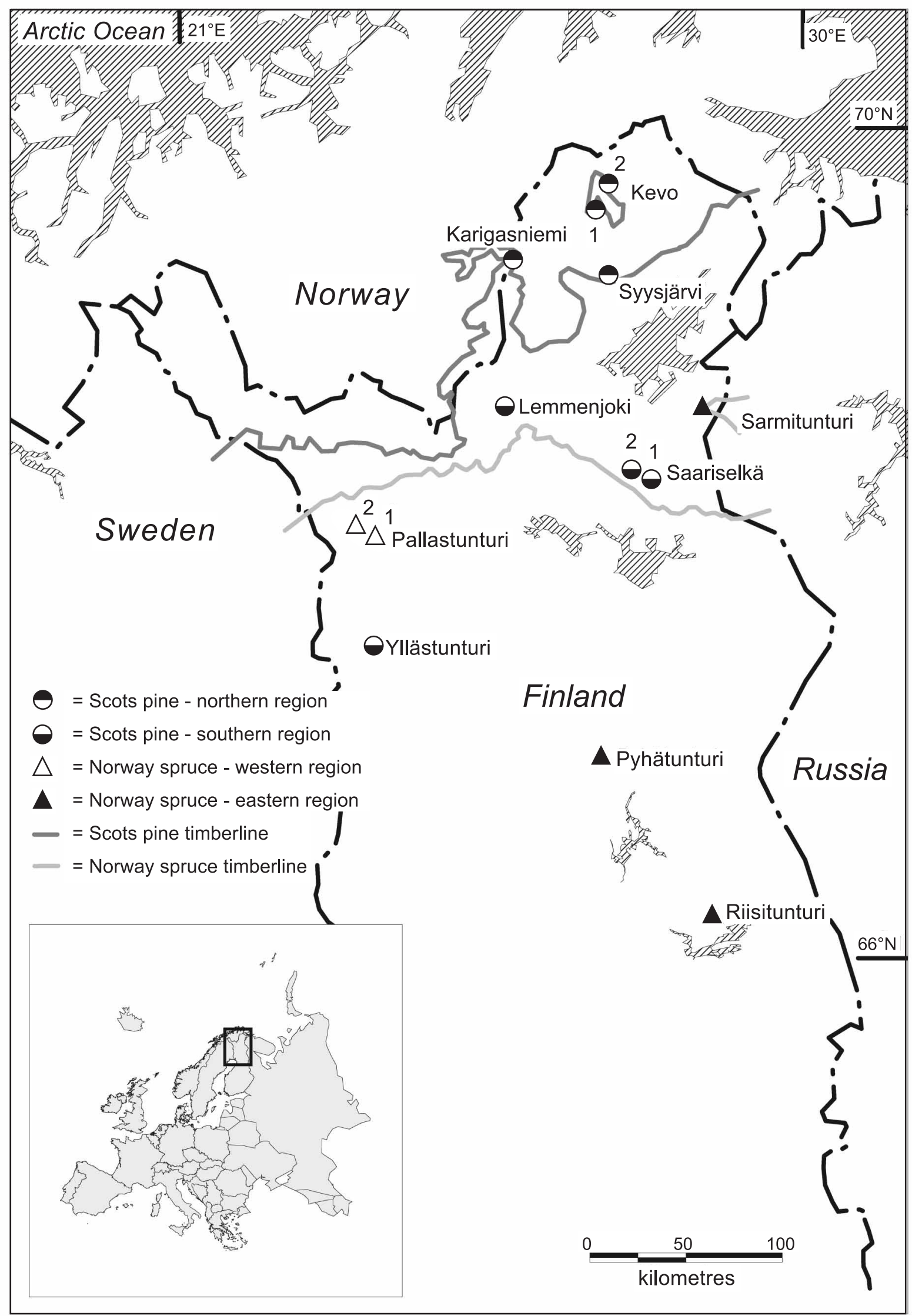

FIG. 1. Map of the monitoring localities in Finnish Lapland, showing the northern timberlines of Scots pine and Norway spruce. 


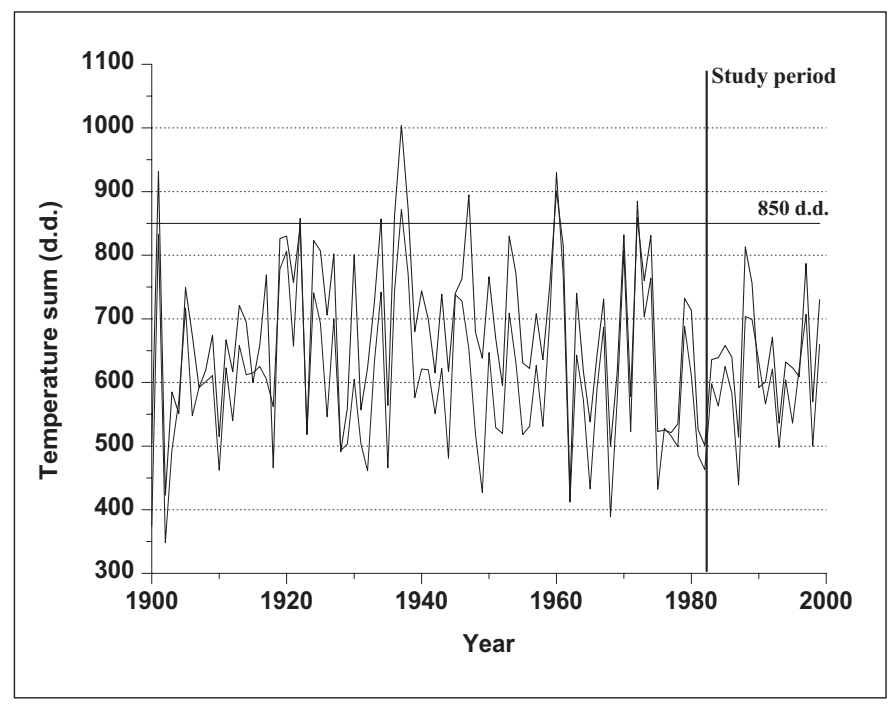

FIG. 2. The calculated effective temperature sum $\left(+5^{\circ} \mathrm{C}\right.$ threshold $)$ in degree-days (d.d.) for the timberline of the northernmost (Kevo - thin line) and southernmost (Riisitunturi - thick line) localities. The temperature sum of 850 d.d. is suggested as the mean value for the $50 \%$ seed maturation of Scots pine (Pinus sylvestris) (Henttonen et al., 1986; Harju et al., 1996; Almqvist et al., 1998).

The timberline is located at altitudes of $340-410 \mathrm{~m}$ a.s.l., and the annual mean temperature sum ranges between 589 and 651 d.d. (Table 1). The underlying bedrock is granulite or granitoid (Koljonen et al., 1992).

The localities in the $\mathrm{S}-\mathrm{W}$ region are within a specific climatic area that is sheltered from maritime influence by the Scandian Mountains (Hämet-Ahti, 1963). The underlying bedrock consists of metasediment and volcanogenic rock, mafic and ultramafic intrusive rock, and mafic and ultramafic rock as a layered intrusion (Koljonen et al., 1992). The till derived from this is fine-textured and fertile, and therefore favorable for spruce. The timberline is located at altitudes of $445-480 \mathrm{~m}$ a.s.l., and the annual mean temperature sum varies from 594 to 619 d.d. (Table 1).

The distances between the localities in the $\mathrm{S}-\mathrm{E}$ region are long (about $330 \mathrm{~km}$ ) in the south-north direction; therefore, the underlying bedrock is heterogeneous, varying from metasediment and volcanogenic rock to greenstone and gabbro (Koljonen et al., 1992). One common characteristic is that the rock types contain mostly fine-grained and rather easily soluble basic minerals. The tills derived from these kinds of rock are predominantly occupied by spruce. The climate is relatively continental (Tuhkanen, 1980). The timberline is located at altitudes of $370-440 \mathrm{~m}$ a.s.l., and the annual mean temperature ranges between 607 and 696 d.d. (Table 1).

\section{Sampling Design and Measurements}

The timberline-monitoring project is being carried out by the Finnish Forest Research Institute and the northern field stations of the universities of Helsinki, Oulu, and Turku (Kallio et al., 1986). This paper refers to the period $1983-89$, but the project is ongoing: measurements will be taken next in 2004 and every five years thereafter.

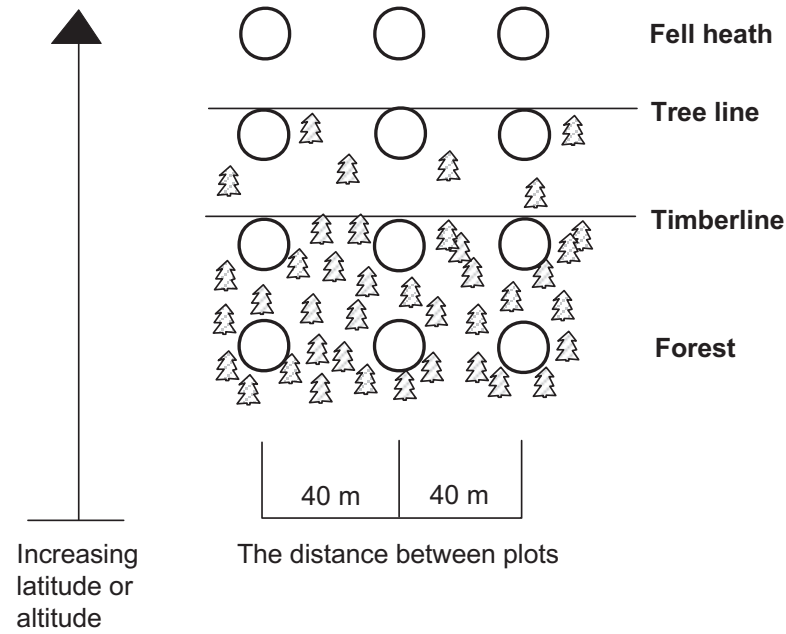

FIG. 3. Experimental design. The altitudinal difference between forest and tree line plots varies from 10 to $195 \mathrm{~m}$, and the horizontal distance, from 0.1 to 11.5 $\mathrm{km}$. The distance between the circular plots is measured from centre to centre.

Each of the 13 localities consists of 3-4 rows of three circular monitoring plots along an altitudinal gradient from forest to timberline to tree line (Fig. 3). The distance between the centres of adjacent monitoring plots is $40 \mathrm{~m}$. In each locality, the first row established was located as near as possible to the estimated coniferous timberline. "Timberline" is defined here as the elevational limit at which forest canopy closure ceases (Hustich, 1966). There was apparently some variation among the observers in applying this definition, but we feel that it is not a problem because the focus is on changes occurring in the study plots and not on the movement of the timberline. The lowest row was then established in a forest stand representing the characteristics of the forest zone. It was placed so that its vertical distance from the timberline row was at least $20 \mathrm{~m}$, or its horizontal distance over $100 \mathrm{~m}$, or both. The third row was established within the "tree line zone," i.e., just below the tree line, where the distance between solitary trees higher than $2 \mathrm{~m}$ does not exceed $100 \mathrm{~m}$. In some localities (see Table 1), a fourth row was located above the coniferous tree line, in the mountain birch zone or treeless area (fell heath). The timberline ecotone in this context contains the entire transition belt, extending from closed coniferous forest up to the fell heath. The total number of plots in the project is 141. Most of the plots have an area of $300 \mathrm{~m}^{2}$ (radius $9.8 \mathrm{~m}$ ); however, in places where there were only a few trees, $500 \mathrm{~m}^{2}$ plots (radius $12.6 \mathrm{~m}$ ) were used (Table 1).

In 1983 and 1984, we established the plots and carried out the first mapping (referred to in the text as the 1983 inventory) (Kallio et al., 1986). The second inventory was made on the same plots in 1994, and the third in 1999. We mapped the distance and direction from the central point of all the trees (height $\geq 2 \mathrm{~m}$ ) and seedlings $(<2 \mathrm{~m})$ within each monitoring plot and measured the diameter of the 
TABLE 1. Coordinates, altitude, temperature sum, and horizontal distance between the zones in each locality. Coordinates and temperature sums are focused on the timberline zones. The average temperature sums were calculated for the period 1900-97 using the program of Ojansuu and Henttonen (1983).

\begin{tabular}{|c|c|c|c|c|c|c|c|c|c|c|}
\hline \multirow[b]{2}{*}{ Locality } & \multirow[b]{2}{*}{ Latitude } & \multirow[b]{2}{*}{ Longitude } & \multirow[b]{2}{*}{$\begin{array}{l}\text { Dominant } \\
\text { conifer }^{1}\end{array}$} & \multicolumn{4}{|c|}{ Altitude (m a.s.1.) } & \multirow[b]{2}{*}{$\begin{array}{l}\text { Temperature } \\
\text { sum (d.d.) }\end{array}$} & \multicolumn{2}{|c|}{$\begin{array}{c}\text { Horizontal distance } \\
(\mathrm{m}) \text { between }\end{array}$} \\
\hline & & & & $\begin{array}{l}\text { Forest } \\
\text { zone }\end{array}$ & Timberline & Tree line & $\begin{array}{l}\text { Fell heath } \\
\text { zone }\end{array}$ & & $\begin{array}{l}\text { Forest and } \\
\text { timberline }\end{array}$ & $\begin{array}{l}\text { Timberline } \\
\text { and tree line }\end{array}$ \\
\hline Kevo 1 & $69^{\circ} 40.706^{\prime}$ & $26^{\circ} 58.905^{\prime}$ & $\mathrm{P}$ & 110 & 180 & 190 & - & 607 & 310 & 180 \\
\hline Kevo 2 & $69^{\circ} 44.588^{\prime}$ & $27^{\circ} 03.089^{\prime}$ & $\mathrm{P}$ & 185 & 210 & 225 & - & 581 & 230 & 100 \\
\hline Karigasniemi & $69^{\circ} 24.804^{\prime}$ & $25^{\circ} 53.390^{\prime}$ & $\mathrm{P}$ & 225 & 275 & 420 & 430 & 597 & 840 & 810 \\
\hline Syysjärvi & $69^{\circ} 16.762^{\prime}$ & $27^{\circ} 11.819^{\prime}$ & $\mathrm{P}$ & 215 & 220 & 225 & - & 644 & 1280 & 11460 \\
\hline Lemmenjoki & $68^{\circ} 42.979^{\prime}$ & $26^{\circ} 06.284^{\prime}$ & $\mathrm{P}$ & 285 & 375 & $415^{*}$ & $445^{*}$ & 589 & 460 & 130 \\
\hline Saariselkä 1 & $68^{\circ} 27.767^{\prime}$ & $27^{\circ} 26.379^{\prime}$ & $\mathrm{P}$ & 315 & 340 & $370 *$ & $400 *$ & 620 & 140 & 210 \\
\hline Saariselkä 2 & $68^{\circ} 27.898^{\prime}$ & $27^{\circ} 22.151^{\prime}$ & $\mathrm{P}$ & 340 & 380 & $400 *$ & - & 597 & 250 & 270 \\
\hline Ylläs & $67^{\circ} 34.429^{\prime}$ & $24^{\circ} 11.395^{\prime}$ & $\mathrm{P}$ & 380 & 410 & $465^{*}$ & $520 *$ & 651 & 240 & 210 \\
\hline Pallastunturi 1 & $68^{\circ} 00.323^{\prime}$ & $24^{\circ} 09.159^{\prime}$ & $\mathrm{S}$ & 410 & 445 & $465^{*}$ & $490 *$ & 619 & 250 & 120 \\
\hline Pallastunturi 2 & $68^{\circ} 02.171^{\prime}$ & $24^{\circ} 05.726^{\prime}$ & $\mathrm{S}$ & 465 & 480 & $500 *$ & $565^{*}$ & 594 & 220 & 110 \\
\hline Sarmitunturi & $68^{\circ} 39.202^{\prime}$ & $28^{\circ} 23.429^{\prime}$ & $\mathrm{S}$ & 340 & 370 & $410 *$ & $425 *$ & 607 & 150 & 160 \\
\hline Pyhätunturi & $67^{\circ} 01.060^{\prime}$ & $27^{\circ} 06.866^{\prime}$ & $\mathrm{S}$ & 380 & 400 & 420 & 470 & 696 & 300 & 260 \\
\hline Riisitunturi & $66^{\circ} 13.360^{\prime}$ & $28^{\circ} 33.307^{\prime}$ & $\mathrm{S}$ & 420 & 440 & $460 *$ & - & 677 & 120 & 190 \\
\hline
\end{tabular}

${ }^{1}$ Dominant conifer species: $\mathrm{P}=$ pine, $\mathrm{S}=$ spruce.

* Indicates that a larger area $\left(500 \mathrm{~m}^{2}\right)$ has been used.

trees at breast height. Mountain birch was also measured in the same way. However, comparison of the birch seedling and tree densities between the inventories was unreliable since stems of polycormic mountain birch might have been defined as trees or as offshoots; therefore, only the basal area of birch was used in the data analyses of this study.

\section{Statistical Analyses}

The seedling density, tree density, and basal area of the trees taller than $2 \mathrm{~m}$ were calculated on each plot. The changes in seedling $(<2 \mathrm{~m})$ and tree $(\geq 2 \mathrm{~m})$ density of pine and spruce and the changes in the basal area of pine, spruce, and mountain birch from 1983 to 1999 were analyzed in each zone. Before analyzing each data set, we tested the homogeneity of variance with the Levene test and the normal distribution with the Kolmogorov-Smirnov test (Sokal and Rohlf, 1981).

The stand structure of each zone at the beginning of the study period was described using the arithmetic means of the baseline inventory. The homogeneity of stand structure among the regions and among the localities within the regions in 1983 was estimated using analysis of variance (ANOVA), with Locality (L) as a within-subject factor. In the model, Region (R) was set as a fixed factor, and $\mathrm{L}$ as a random factor (Zar, 1984; Potvin et al., 1990; see also Tuomisto and Neuvonen, 1993).

We tested the effects of R, Zone (Z), and their interaction on the change in seedling and tree density over all the data using ANOVA with a split-plot design, in which $\mathrm{R}$ and $\mathrm{Z}$ were treated as fixed effects, and $\mathrm{L}$ as a random effect nested within R (see Potvin et al., 1990). The analysis was performed separately for pine and spruce. Type III sum of squares was used. The analyses were performed on logarithmically transformed values; for seedling and tree density, the transformation was $\ln (x+20)$; for basal area, it was $\ln (x+1)$.

All the plots were included in the ANOVAs, but plots with no seedlings or trees were not included in the values of relative changes presented in the text. The relative change for each zone is a geometric mean calculated by back-transforming the mean of the logarithmically transformed values.

\section{RESULTS AND DISCUSSION}

\section{Baseline Inventory (1983)}

The baseline inventory in 1983 showed that there is significant regional and local variation in forest stand structures near the timberlines (Table 2, Fig. 4). This spatial variability affects the prospects for the future, and it should be taken into account when modeling the advance of timberlines under different climatic scenarios (cf. Kellomäki et al., 1997).

In the pine-dominated areas, seedling density and basal area decreased sharply toward the upper sites on the slopes. Pine tree density was similar in the forest and at the timberline, but it decreased sharply at the tree line (Fig. 4). In the $\mathrm{P}-\mathrm{S}$ region, the mean seedling and tree densities in all the zones were two or three times higher than in the corresponding P-N region, but basal area was only slightly higher. There was high variation among the localities within the regions; therefore, only the difference in seedling densities at the tree line was significant (Table 2).

Spruce seedling density almost doubled up to the timberline, and at the tree line it was close to the level in the forest zone (Fig. 4). The tree density and basal area decreased evenly towards upper sites. The number of 
TABLE 2. Analysis of variance (ANOVA) for seedling and tree density $\left(\mathrm{ha}^{-1}\right)$ and basal area of conifers $\left(\mathrm{m}^{2} / \mathrm{ha}\right)$ for each region in the different zones from the first inventory (1983-84). In the Variability columns, F-values with their significance are presented. For basal area of mountain birch $\left(\mathrm{m}^{2} / \mathrm{ha}\right)$, only mean values are shown.

\begin{tabular}{|c|c|c|c|c|c|c|c|c|c|c|c|c|}
\hline \multirow[b]{2}{*}{ Tree species } & \multirow[b]{2}{*}{ Zone } & \multirow[b]{2}{*}{ Region $^{1}$} & \multicolumn{3}{|c|}{ Variability } & \multicolumn{3}{|c|}{ Variability } & \multicolumn{3}{|c|}{ Variability } & \multirow[b]{2}{*}{$\begin{array}{c}\text { Mountain } \\
\text { birch basal } \\
\text { area }\left(\mathrm{m}^{2} / \mathrm{ha}\right)\end{array}$} \\
\hline & & & $\begin{array}{c}\text { Seedling } \\
\text { density } \\
\text { (number/ha) }\end{array}$ & $\begin{array}{l}\text { Between } \\
\text { regions }\end{array}$ & $\begin{array}{l}\text { Within } \\
\text { regions }\end{array}$ & $\begin{array}{c}\text { Tree } \\
\text { density } \\
\text { (number/ha) }\end{array}$ & $\begin{array}{l}\text { Between } \\
\text { regions }\end{array}$ & $\begin{array}{l}\text { Within } \\
\text { regions }\end{array}$ & $\begin{array}{c}\text { Conifer } \\
\text { basal area } \\
\left(\mathrm{m}^{2} / \mathrm{ha}\right)\end{array}$ & $\begin{array}{c}\text { Between } \\
\text { regions }\end{array}$ & $\begin{array}{l}\text { Within } \\
\text { regions }\end{array}$ & \\
\hline \multirow[t]{6}{*}{ Pine } & \multirow[t]{2}{*}{ forest } & north & 1011 & \multirow[t]{2}{*}{2.99} & \multirow[t]{2}{*}{$6.41 * *$} & 244 & \multirow[t]{2}{*}{3.83} & \multirow[t]{2}{*}{$3.52^{*}$} & 9.78 & \multirow[t]{2}{*}{0.01} & \multirow[t]{2}{*}{1.62} & 2.15 \\
\hline & & south & 1811 & & & 456 & & & 10.08 & & & 1.19 \\
\hline & \multirow[t]{2}{*}{ timberline } & north & 350 & \multirow[t]{2}{*}{1.43} & \multirow[t]{2}{*}{$4.91 * *$} & 274 & \multirow[t]{2}{*}{0} & \multirow[t]{2}{*}{$3.73^{*}$} & 4.82 & \multirow[t]{2}{*}{1.66} & \multirow[t]{2}{*}{2.36} & 4.09 \\
\hline & & south & 1130 & & & 411 & & & 5.82 & & & 1.17 \\
\hline & \multirow[t]{2}{*}{ tree line } & north & 50 & \multirow[t]{2}{*}{$8.11 *$} & \multirow[t]{2}{*}{2.32} & 6 & \multirow[t]{2}{*}{3.83} & \multirow[t]{2}{*}{$3.72 *$} & 0 & \multirow[t]{2}{*}{3.23} & \multirow[t]{2}{*}{1.40} & 5.21 \\
\hline & & south & 193 & & & 47 & & & 0.44 & & & 0.03 \\
\hline \multirow[t]{6}{*}{ Spruce } & \multirow[t]{2}{*}{ forest } & west & 1722 & \multirow[t]{2}{*}{$23.18^{*}$} & \multirow[t]{2}{*}{1.64} & 283 & \multirow[t]{2}{*}{0.09} & \multirow[t]{2}{*}{$4.98 *$} & 13.52 & \multirow[t]{2}{*}{1.17} & $10.04 * *$ & 2.21 \\
\hline & & east & 218 & & & 348 & & & 12.19 & & & 2.94 \\
\hline & timberline & west & 3027 & $20.41 *$ & 1.00 & 156 & 0.34 & 3.31 & 8.85 & 0.03 & $12.14^{* *}$ & 3.05 \\
\hline & & east & 470 & & & 259 & & & 7.36 & & & 2.34 \\
\hline & tree line & west & 1080 & 7.46 & 2.11 & 37 & 0.24 & 1.71 & 1.74 & 0.76 & $5.34 *$ & 1.60 \\
\hline & & east & 219 & & & 55 & & & 0.53 & & & 1.99 \\
\hline
\end{tabular}

${ }^{1} \mathrm{P}-\mathrm{N}=$ Pine - north, $\mathrm{P}-\mathrm{S}=$ Pine - south, $\mathrm{S}-\mathrm{W}=$ Spruce - west, $\mathrm{S}-\mathrm{E}=$ Spruce - east.

$* p<0.05 ; * * p<0.01 ; * * * p<0.001$

seedlings was significantly higher in the forest and at the timberline in the $\mathrm{S}-\mathrm{W}$ region than in the $\mathrm{S}-\mathrm{E}$ region (Table 2). Tree densities and basal area in the S-W and SE regions were more or less similar in each of the zones. Spruce seedling densities among the localities within each region were homogeneous, but tree densities and basal area varied significantly (Table 2 ).

The basal area of mountain birch was rather evenly distributed in the different zones (from 2.0 to $2.8 \mathrm{~m}^{2} / \mathrm{ha}$ ), but its proportion out of the total basal area increased markedly with increasing elevation. Although regional variation was relatively low in the forest and at the timberline $\left(1.2-4.1 \mathrm{~m}^{2} / \mathrm{ha}\right.$ ) (Table 2), the basal area of mountain birch varied strongly among the localities within the regions (data not shown). At the tree line, the birch basal area was higher in the P-N region $\left(5.2 \mathrm{~m}^{2} / \mathrm{ha}\right)$, and clearly lower in the $\mathrm{P}-\mathrm{S}$ region $\left(0.03 \mathrm{~m}^{2} / \mathrm{ha}\right)$, than in the other regions.

\section{Changes in Seedling Density}

The pine seedling densities decreased slightly in the different zones from the early 1980 s to 1999 , but the overall decreases (24\% for forest, $28 \%$ for timberline, and $4 \%$ for tree line) were not significant. For spruce, however, the changes in seedling density among the zones differed very significantly (Table 3 ). The change was small in the forest and at the timberline $(-16 \%$ and $+14 \%$, respectively), but at the tree line the spruce seedling density more than doubled $(+154 \%)$ from the early 1980 s to 1999 .

The number of pine seedlings increased on $42 \%, 39 \%$, and $25 \%$ of the plots in the forest, timberline and tree line, respectively. The corresponding numbers for spruce were $40 \%, 67 \%$, and $87 \%$. It is generally postulated that summer temperatures are the primary influence on changes in timberline position and structure (Hustich, 1948; Kullman, 1981, 1992; Henttonen et al., 1986; Kellomäki et al., 1997). The temperature sum required for $50 \%$ maturation of the pine seed crop varies in different studies from 800 to 890 d.d. (Henttonen et al., 1986; Harju et al., 1996; Almqvist et al., 1998), and it is about 100 d.d. lower for spruce (Almqvist et al., 1998). Since the regeneration process from bud formation to seed maturation takes three summers for Scots pine, certain climatic conditions must also be fulfilled during the two years preceding a summer with seed maturation to ensure successful formation of regenerative buds, flowering, and seed formation (Sarvas, 1962, 1970; Kellomäki et al., 1997). The probability of achieving conditions propitious for the successful regeneration of pine at the timberline has been suggested to be about 0.02-0.03 (Henttonen et al., 1986; Kellomäki et al., 1997). However, in the first half of the 20th century, several good seed years were recorded even at high elevations (Hustich, 1948, 1966). Furthermore, at least three regeneration peaks have occurred in northern Fennoscandia since 1950, in the years 1950-51, 1961, and 1972-73 (Sirén, 1993). Natural regeneration was also observed in the tree line zone during the period 1983-99, although none of the summers were exceptionally warm (Fig. 2).

The finding that the regeneration of pine and spruce in high-altitudinal stands in northern Fennoscandia has not been limited very much by summer temperatures during recent decades is in agreement with the results of Stöcklin and Körner (1999) and Kullman (2000). According to Ryynänen (1982), the variation in seed quality between trees is high in the northern areas, especially in unfavorable seed years. Therefore, seeds are also produced to some extent in average years in northern timberline areas. Lack of a suitable growing substrate and high seedling mortality induced by different forms of climatic stress are also 


\section{Scots pine}
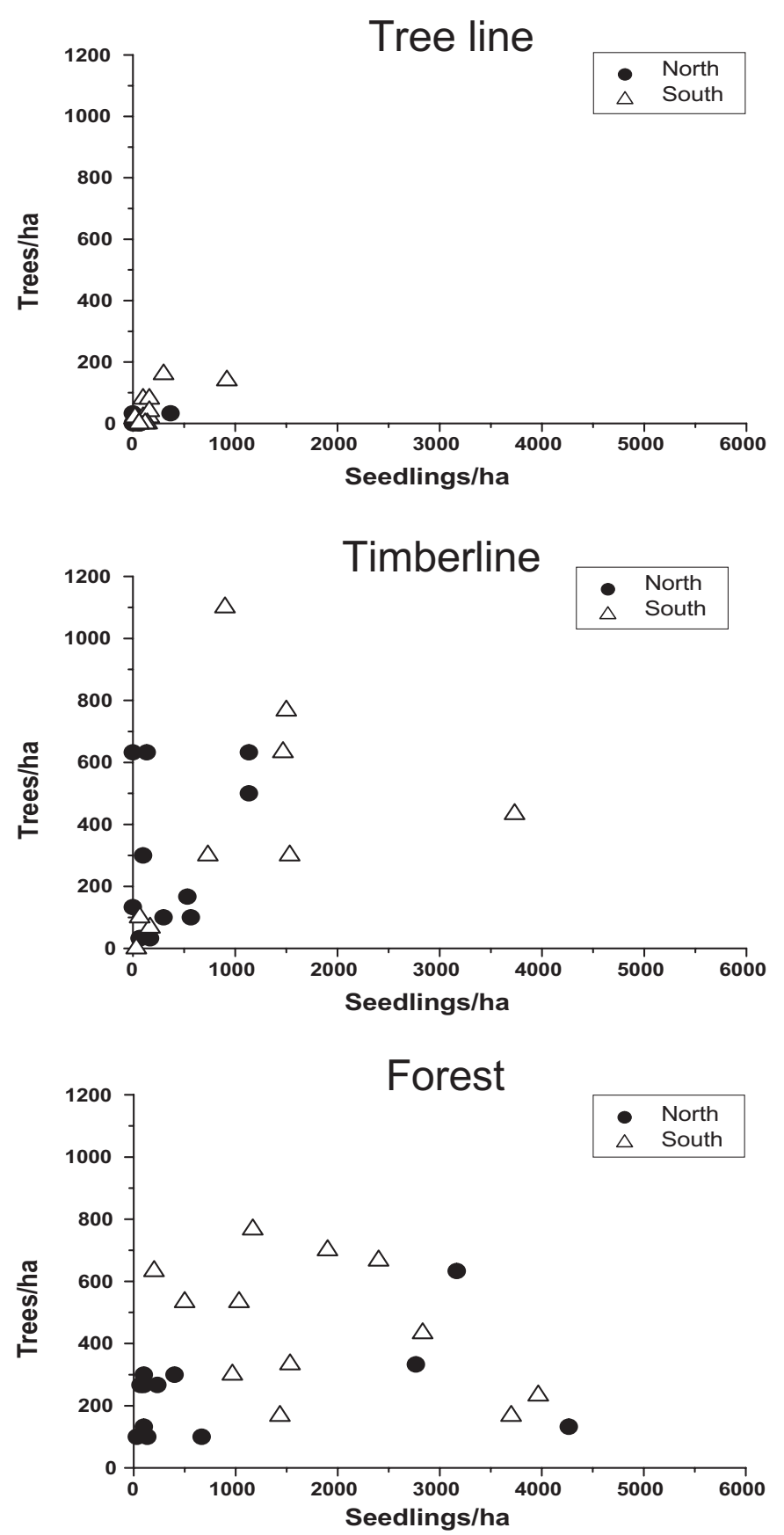

\section{Norway spruce}
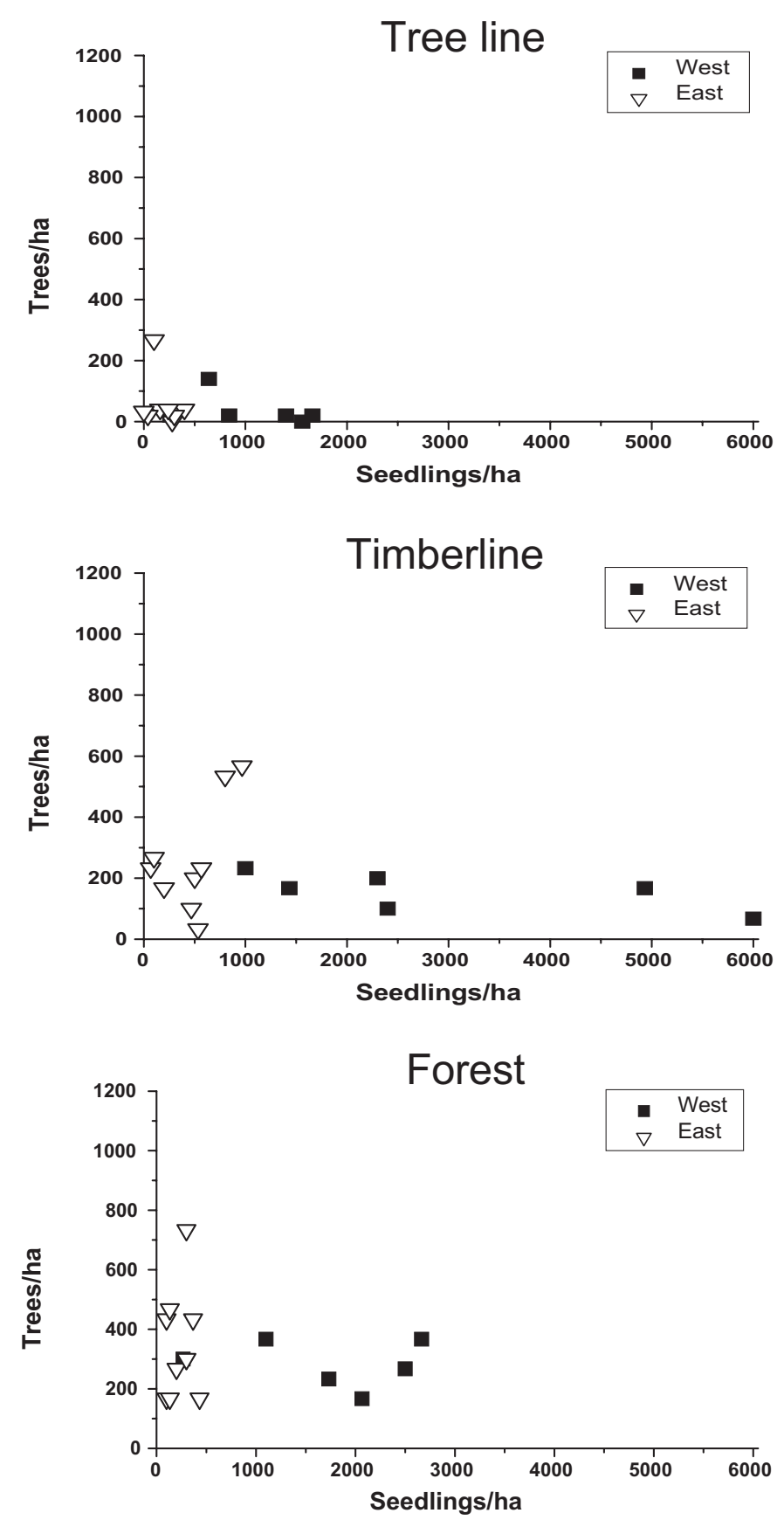

FIG. 4. Seedling density and tree density of Scots pine and Norway spruce on the study plots in different zones in 1983.

important in controlling seedling establishment in highaltitudinal stands (Holtmeier, 2000).

The changes in pine seedling density differed between the regions (Table 3); there was a noticeable decrease in the P-S region, while the seedling density increased slightly in the P-N region. The ultimate reason for this regional variability is not known. The difference was especially clear at the timberline, where reduction in seedling density occurred in the southern localities, especially between 1983 and 1994 (Fig. 5). Some seedlings in the first inventory have attained tree size, but the increase in tree density is not enough to explain the loss in the number of seedlings. Notable seedling mortality therefore occurred in the P-S region during the period 1983-94 (Fig. 5), but the 


\section{Seedling density}
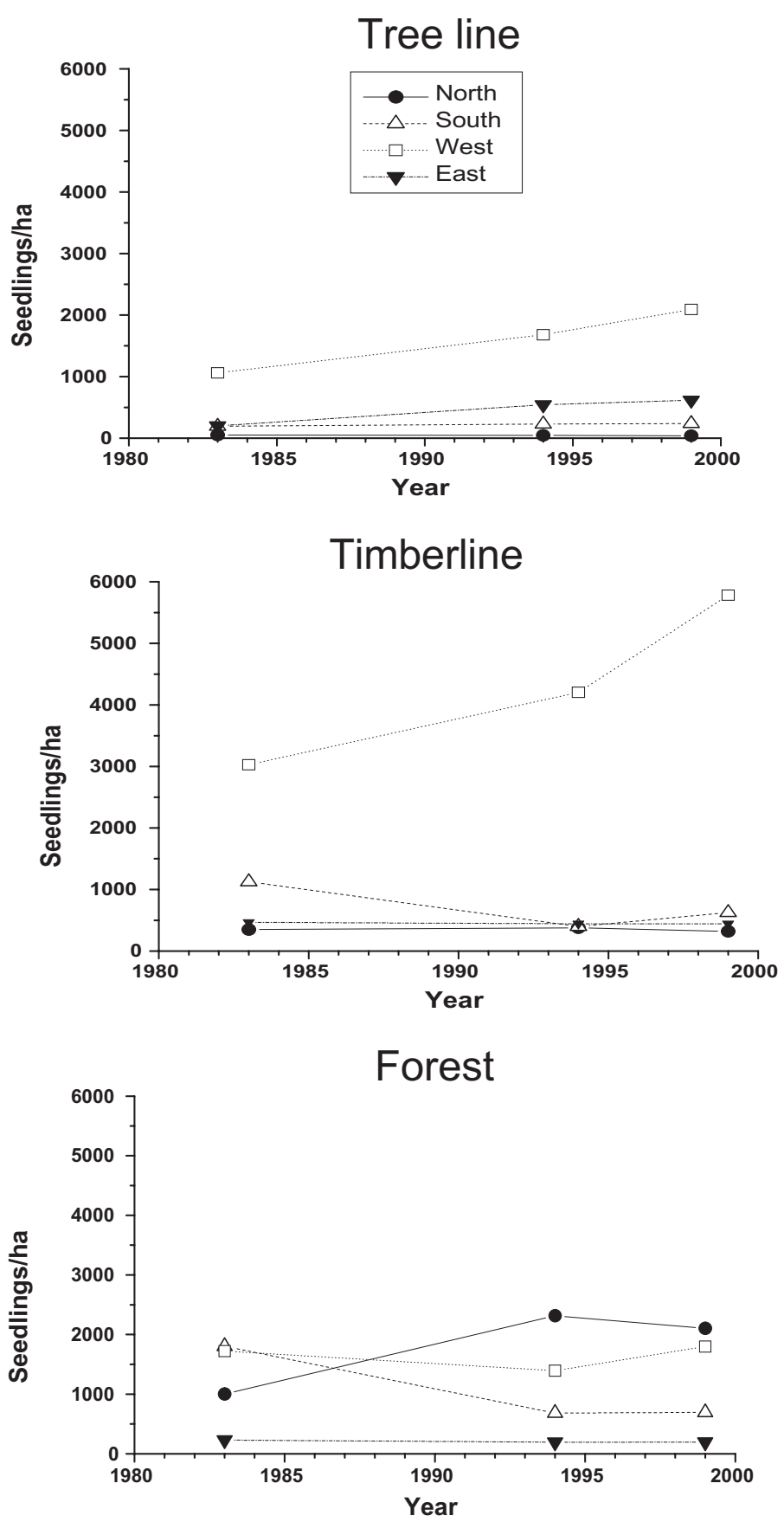

\section{Tree density}
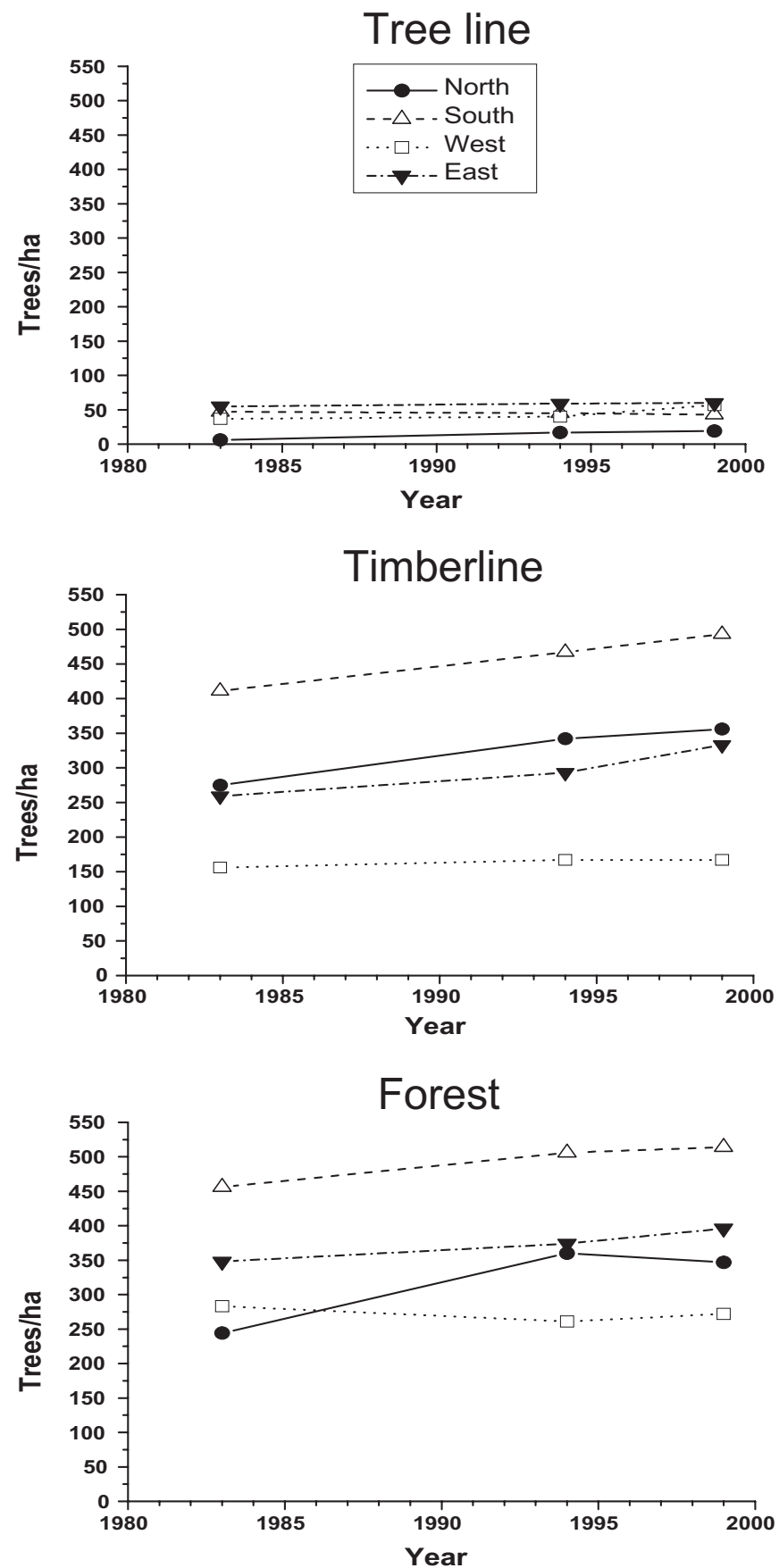

FIG. 5. Seedling density and tree density of Scots pine and Norway spruce in the different zones in 1983, 1994, and 1999. The northern and southern regions consist of Scots pine, and the western and eastern regions of Norway spruce.

exact year(s) when it occurred cannot be determined. There was no corresponding reduction in the number of spruce seedlings.

Climatic stress involves a number of processes that could be fatal to seedlings. Firstly, frost damage in late winter or early summer, caused by temperatures that fluctuate above and below $0{ }^{\circ} \mathrm{C}$, is one of the main threats to successful seedling establishment (Cannell and Smith,
1986). Seedlings are most susceptible to frost damage during bud burst, when the needles start growing (Rikala and Repo, 1987; Hannerz, 1994). A temperature only a few degrees below $0^{\circ} \mathrm{C}$ can cause injury to growing seedlings (Rikala and Repo, 1987; Junttila and Skaret, 1990). Secondly, the winter soil temperature, which is controlled by both the air temperature and depth of the snow cover, may be a critical determinant. Especially in 


\section{Conifers}
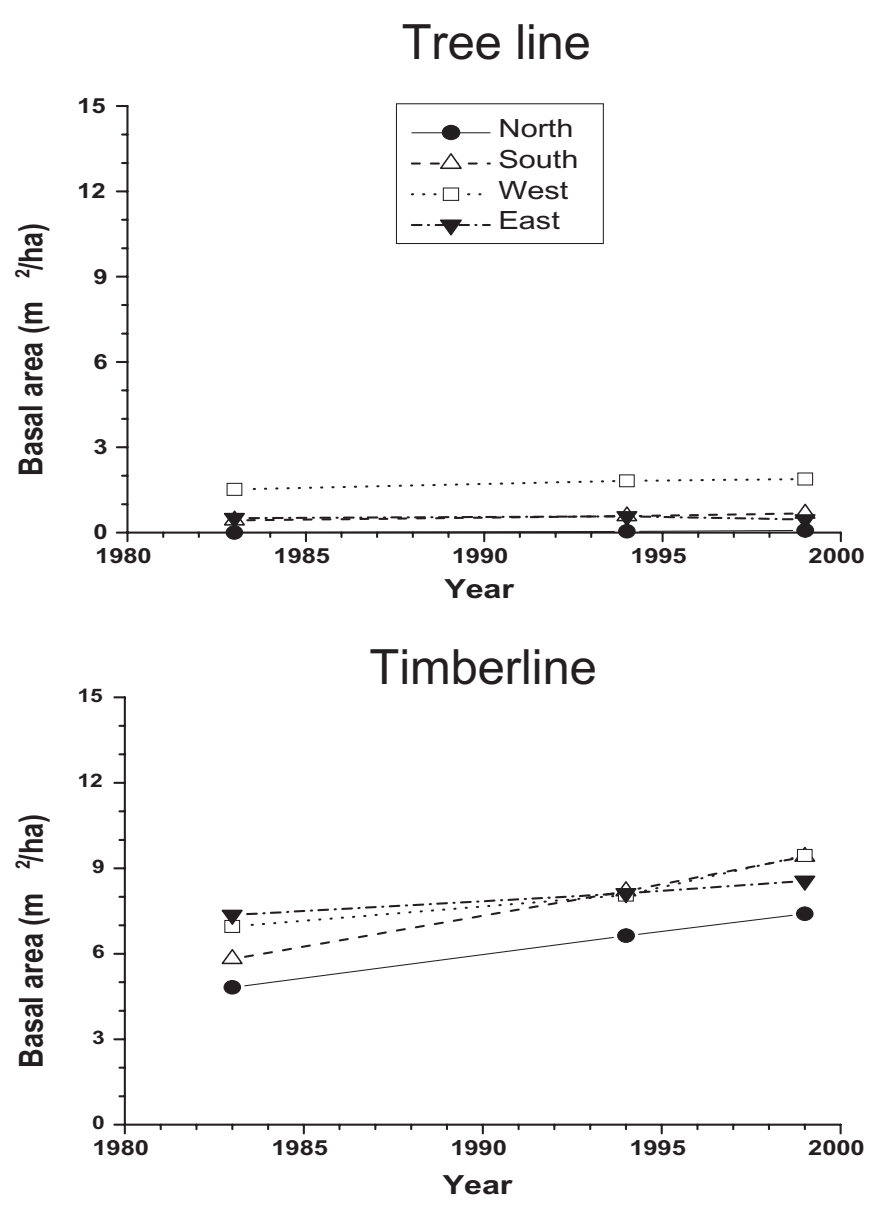

Forest

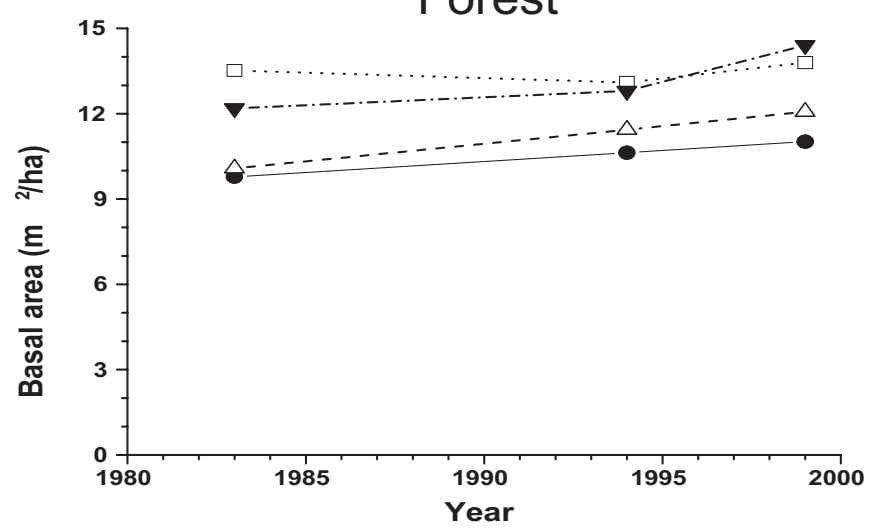

Mountain birch
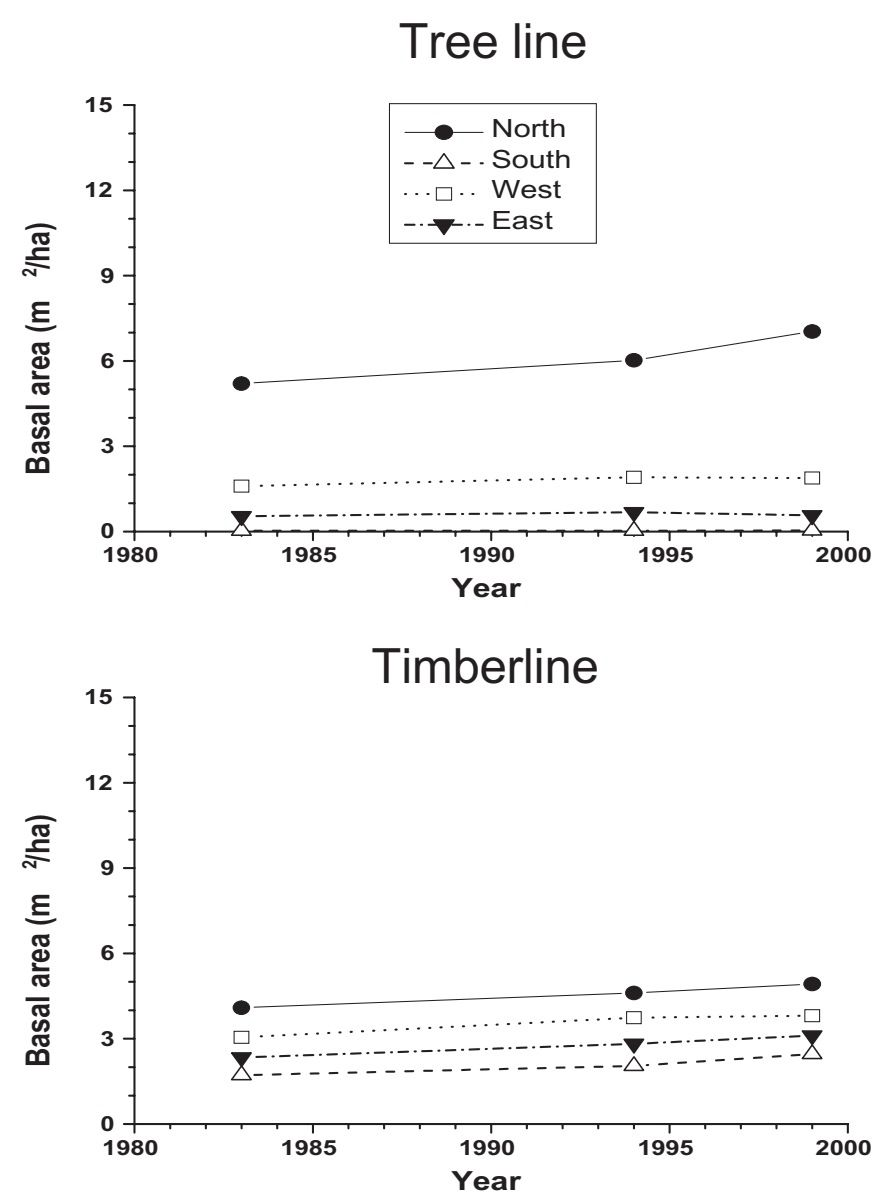

Forest

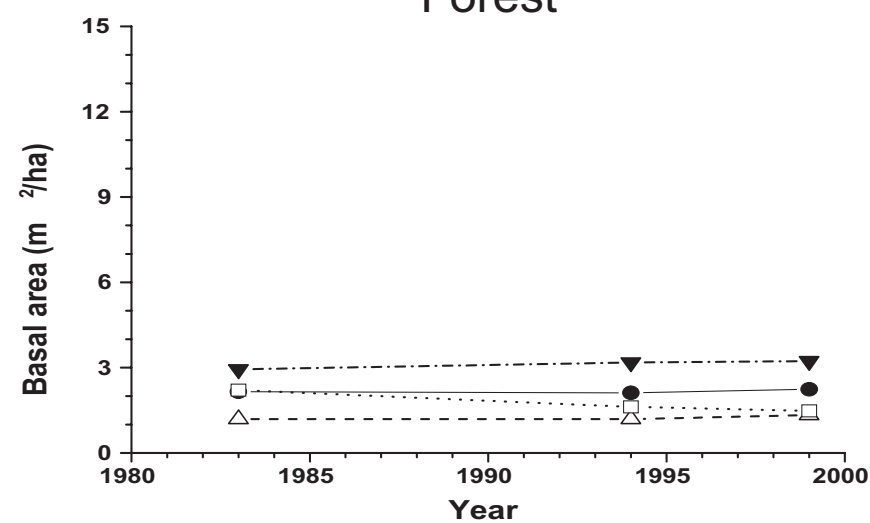

FIG. 6. Basal area of conifers and mountain birch in the different zones in 1983, 1994, and 1999. For conifers, the northern and southern regions refer to Scots pine, and the western and eastern regions to Norway spruce.

years with prolonged and severe soil freezing, the branches above the snow cover suffer from acute winter desiccation, which may lead to the death of seedlings (Kullman, 1997). The susceptibility of seedlings to winter desiccation increases farther up the slopes where the winds are stronger and snow cover is thinner (Kjällgren and Kullman, 1998). Thirdly, the winters during the 1980s and 1990s had more snow (Solantie, 2000). Longer periods with a snow cover can predispose seedlings to fungal diseases like pine snow blight (Phacidium infestans Karsten), which thrives at sites with a thick snow cover (Stöcklin and Körner, 1999). Moreover, severe stress from harsh climate in high-elevation stands may predispose seedlings and trees to diseases caused by viruses or insects (Holopainen, 1986). 
TABLE 3. Effects of zone, region, locality (nested within region), and interaction between zone and region on the changes in seedling density, stem number, and basal area from 1983 to 1999.

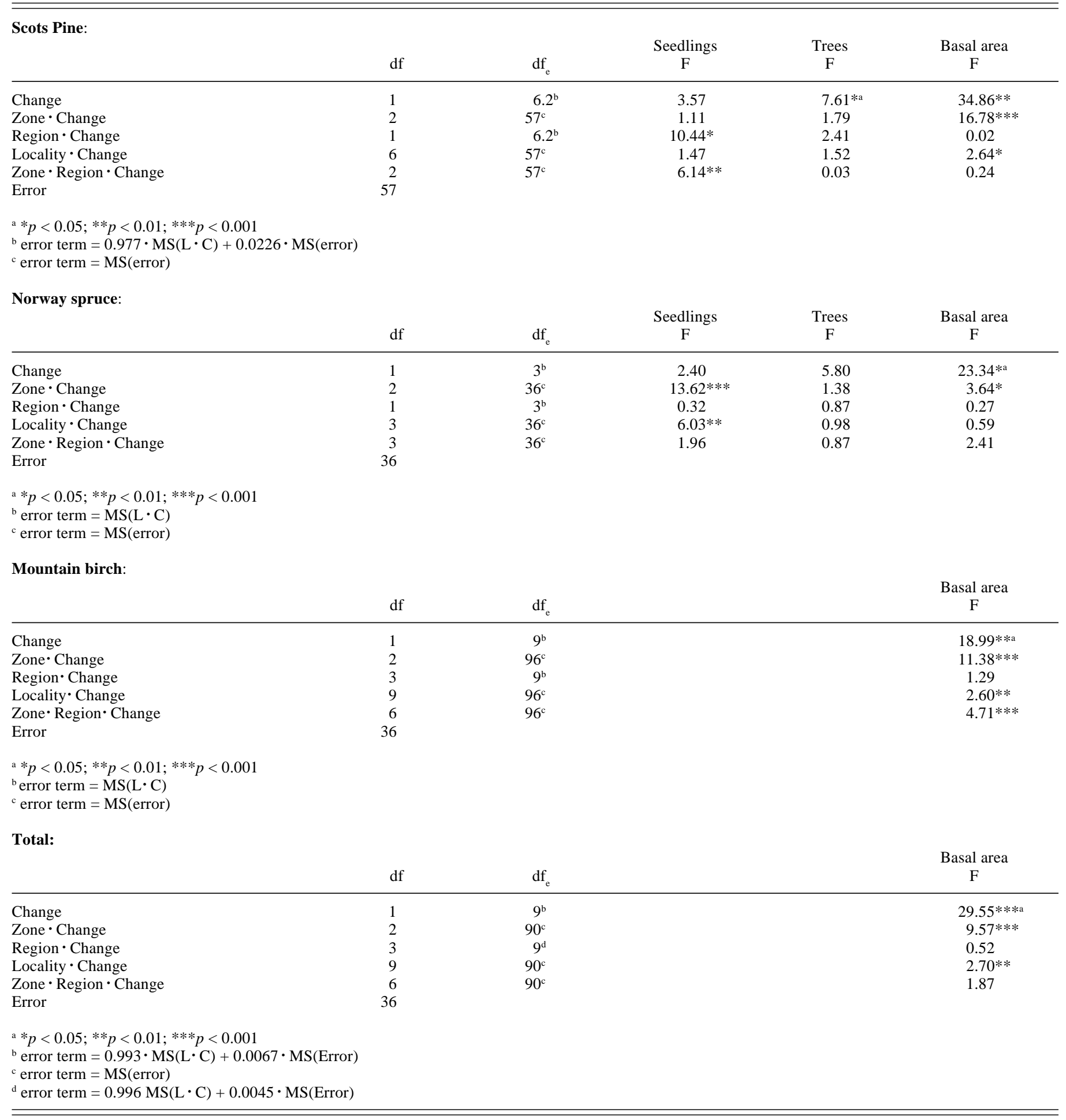

\section{Changes in Tree Density}

Tree density increased evenly in both the pine- and spruce-dominated localities in all the zones and regions (Fig. 5). Pine tree density increased by $23 \%$ in the forest, $31 \%$ at the timberline, and $29 \%$ at the tree line. The average change over all the zones was significant (Table 3).
Neither region nor zone had any significant effect on the changes (Table 3), although the relative changes tended to be more positive in the P-N than in the P-S region. The spruce tree density remained constant in the forest (change $+2 \%)$, but increased at both the timberline $(+23 \%)$ and the tree line $(+35 \%)$; the change was not significant in any zone, but it was almost significant at the tree line. The 
overall change in the spruce tree density was also close to significant. The changes did not differ statistically among the zones (Table 3), although the increase was higher at the upper sites.

According to Kullman (1997; see also Kullman, 2000), Scots pine seedlings from the 1950s and even the 1930s did not attain tree size until the 1980s and 1990s, and therefore the timberline and tree line have risen. Our results clearly suggest that new trees have supplemented the timberline and tree line zones in northern Finland since the beginning of the 1980s. This implies that the limits between closed canopy and open forest, and between open forest and the treeless area, have also advanced upward-the same seems to have occurred in the Swedish Scandes Mountains (Kullman, 2000, 2001; Kullman and Kjällgren, 2001). No signs of growth form regression were found at our monitoring sites. Overall, the number of pine trees had increased on 28 plots and decreased on 9 , while the number of spruce trees had increased on 19 plots and decreased on 4 plots.

The significant increase in tree density clearly indicates low rates of sapling and tree mortality during the monitoring period. This could be explained by the favorable winter/spring conditions (Kullman, 1991). The main threats to trees in temperature-limited environments are premature bud burst during mild spells in late winter or early spring, resulting in heavy frost damage (Dormling, 1982; Hänninen, 1991), and winter desiccation and root damage caused by ground frost (Sutinen et al., 1998). During the exceptionally cold and snow-poor early winter in 1987, acute frost desiccation occurred as a result of severe ground freezing in the Swedish Scandes (Kullman and Högberg, 1989; Kullman, 1991, 1996). Similar fatal episodes have been recorded in northern Finland (Ritari, 1990; Jalkanen et al., 1995). The risk of damage increases toward northern or elevational margins of distribution (Kullman 1996, 2000). In marginal forests, the frequency of extreme climatic episodes (e.g., extremely cold periods, drought and storms) is probably more significant for the survival and performance of seedlings and trees than is variation in the thermal conditions of the growing season. Generally, mature trees are not as sensitive to climatic stress as seedlings are (Brubaker, 1986; Persson and Beuker, 1997).

\section{Changes in the Basal Area}

The basal area of both conifers and mountain birch has increased in all the zones and localities (Fig. 6), and the overall change for pine, spruce, and mountain birch was significant (Table 3). Overall, the basal area of conifers has increased on 98 plots and decreased on 8 plots, and the birch basal area has increased on 82 plots and decreased on 19 plots. Tree growth is related to complex ecological processes that are relatively specific for each species (Brooks et al., 1998). The diameter increment of pine, spruce, and birch shows good correlation with the summer temperature, although the relationship between temperature and growth is not linear (Briffa et al., 1988; Kjällgren and Kullman, 1998; Mäkinen et al., 2000). The lower threshold for tree growth in pine and spruce is about $8.5^{\circ} \mathrm{C}$ (Kullman, 1991), and an increase in the number of degree-days above the limit significantly increases tree growth (Fries et al., 1998). This is true especially in temperature-limited environments. Although the 198399 monitoring period was characterized by relatively modest summer temperatures, even the coldest summers well exceeded the lower threshold for tree growth.

The change in basal areas differed significantly among the zones (Table 3). The increase in the total basal area was higher at the timberline than in the forest zone. The average increase in the basal area of conifers was 1.6 in the forest, 2.3 at the timberline, and $0.2 \mathrm{~m}^{2} / \mathrm{ha}$ at the tree line, and the corresponding values for mountain birch were 0.0 , 0.8 , and $0.6 \mathrm{~m}^{2} / \mathrm{ha}$. The relative increase in the total basal area was the lowest in the forest, $15 \%$. The increases at the timberline and tree line were $46 \%$ and $67 \%$, respectively. The result suggests that intra- and interspecific competition among trees at the upper sites is less intense than that inside the dense forest (Brubaker, 1986; Tham, 1989). Trees grow faster when they are not suppressed by larger neighbors (Nilsson and Gemmel, 1993).

The overall changes in basal area did not show any regional differences. In the case of mountain birch, there was strong zone-region $\cdot$ change interaction (Table 3 ). In the forest zone, there was a slight increase in all regions except the S-W region, where the basal area of mountain birch decreased. At the coniferous timberline, the basal area of mountain birch increased evenly in all four regions. At the tree line, there was only a slight increase in all regions except the $\mathrm{P}-\mathrm{N}$ region, where there was a strong increase (Fig. 6). According to Kullman (2001), the tree line ecotone, especially in the case of mountain birch, is very sensitive to climatic fluctuation, and the response may vary considerably over short distances. The marked variation among the localities within the regions (Table 3 ) highlights the importance of spatial variation in Finnish Lapland.

\section{Conifer Seedling and Tree Establishment on the "Empty" Plots}

In 1983, there were 18 monitoring plots with no coniferous seedlings and 38 plots with no coniferous trees. Three of the plots without coniferous seedlings were located at the timberline, eight at the tree line, and seven above the coniferous tree line. In the third inventory in 1999, three of these plots had a few seedlings. However, as the number of seedlings fell to zero on three plots, the total number of plots without seedlings remained 18 throughout the study period. Four of the plots without tree-sized conifers were at the timberline, 15 at the tree line, and 19 above the coniferous tree line. On four of these plots, some seedlings reached tree size by 1999 . Two of these were at 
the tree line, and two in the fell heath. In contrast, the trees disappeared from two plots during the study period.

\section{SUMMARY}

Our study showed new regeneration and tree establishment near the timberline in northern Finland during recent decades, indicating potential for an advance in the timberline and tree line. The basal areas of conifers increased significantly in the timberline and tree line zones during a period with mean summer temperatures that were slightly below the 20th century average. A recent upward movement of conifer tree lines has also been observed in the Swedish Scandes Mountains (Kullman, 2000, 2001; Kullman and Kjällgren, 2001). These observations suggest that there is a widespread upward/northward advancement of conifer timberlines/tree lines in northern Europe, and that exceptionally warm summers may not be required for tree line advancement, although they undoubtedly speed it up.

\section{ACKNOWLEDGEMENTS}

We greatly appreciate the foresight and enthusiasm of the late Professor Paavo Kallio, one of the founders of this timberlinemonitoring project. Special thanks to Mauri Timonen and Teijo Sirviö for advice and help in drawing the figures, John Derome for revising the language, and all those who assisted in the field work. We thank Leif Kullman and two anonymous referees for constructive comments on an earlier manuscript.

\section{REFERENCES}

ALMQVIST, C., BERGSTEN, U., BONDESSON, L., and ERIKSSON, U. 1998. Predicting germination capacity of Pinus sylvestris and Picea abies seeds using temperature data from weather stations. Canadian Journal of Forest Research 28: $1530-1535$.

BEUKER, E. 1994. Long-term effects of temperature on the wood production of Pinus sylvestris L. and Picea abies (L.) Karst. in old provenance experiments. Scandinavian Journal of Forest Research 9:34-45.

BRIFFA, K.R., JONES, P.D., PILCHER, J.R., and HUGES, M.K. 1988. Reconstructing summer temperatures in northern Fennoscandia back to A.D. 1700 using tree ring data from Scots pine. Arctic and Alpine Research 20:385-394.

BROOKS, R., FLANAGAN, B.L., and EHLERINGER, J.R. 1998. Responses of boreal conifers to climate fluctuations: Indications from tree-ring widths and carbon isotope analyses. Canadian Journal of Forest Research 28:524-533.

BRUBAKER, L. 1986. Responses of tree populations to climatic change. Vegetatio 67:119-130.

CANNELL, M.G.R., and SMITH, R.I. 1986. Climatic warming, spring budburst and frost damage on trees. Journal of Applied Ecology 23(1):177-191.
DORMLING, I. 1982. Frost resistance during bud flushing and shoot elongation in Picea abies. Silva Fennica 16:167-177.

EUROLA, S. 1974. The plant ecology of northern Kiölen, arctic, or alpine? Aquilo Ser. Botanica 13:10-22.

FLEMING, R.A. 1996. A mechanistic perspective of possible influences of climate change on defoliating insects in North America's boreal forests. Silva Fennica 30(2-3):281-294.

FRIES, A., RUOTSALAINEN, S., and LINDGREN, D. 1998. Effects of temperature on the site productivity of Pinus sylvestris and lodgepole pine in Finland and Sweden. Scandinavian Journal of Forest Research 13:128-140.

GATES, D.M. 1990. Climate change and forests. Tree Physiology $7: 1-5$

GREIFENHAGEN, S. 1998. The impact of climate change on fungi in the forest ecosystem. In: Colombo, S.J., and Buse, L.J., eds. The impacts of climate change on Ontario's forests. Ontario Forest Research Information Paper No. 143. 12-14.

HÄMET-AHTI, L. 1963. Zonation of the mountain birch forest in northernmost Fennoscandia. Annales Botanici Fennici 34(4). $127 \mathrm{p}$.

HANNERZ, M. 1994. Damage to Norway spruce (Picea abies (L.) Karst) seedlings caused by a late spring frost. Report No. 5. Uppsala: Forestry Research Institute of Sweden.

HÄNNINEN, H. 1991. Does climatic warming increase the risk of frost damage in northern trees? Plant, Cell and Environment $14: 449-454$.

HARJU, A.M., KÄRKKÄINEN, K., and RUOTSALAINEN, S. 1996. Phenotypic and genetic variation in the seed maturity of Scots pine. Silvae Genetica 45(4):205-211.

HENTTONEN, M., KANNINEN, M., NYGREN, M., and OJANSUU, R. 1986. The maturation of Pinus sylvestris seeds in relation to temperature climate in northern Finland. Scandinavian Journal of Forest Research 1:243-249.

HOLOPAINEN, J. 1986. Damage caused by Lygus rugulipennis Popp. (Heteroptera, Miridae), to Pinus sylvestris L. seedlings. Scandinavian Journal of Forest Research 1:343-349.

HOLTMEIER, F.-K. 2000. Die Höhengrenze der Gebirgswälder. Arbeiten aus dem Institut für Landschaftsökologi, Westfälische Wilhelms-Universität, Vol. 8. 337 p.

HUSTICH, I. 1948. The Scots pine in northernmost Finland and its dependence on the climate in the last decades. Acta Botanica Fennica $42.75 \mathrm{p}$.

1966. On the forest-tundra and northern tree-lines: A preliminary synthesis. Reports from the Kevo Subarctic Research Station 3:1-47.

JALKANEN, R., AALTO, T., DEROME, K., NISKA, K., and RITARI, A. 1995. Männyn neulaskatoon 1987 johtaneet tekijät Pohjois-Suomessa. Metsäntutkimuslaitoksen Tiedonantoja No. 554.

JUDAY, G.P., OTT, R.A., VALENTINE, D.W., and BARBER, V.A. 1997. Forests, climate stress, insects and fire. In: Weller, G., and Anderson, A., eds. Implications of global change in Alaska and the Bering Sea region: Proceedings of a workshop held at the University of Alaska Fairbanks on 3-6 June 1997. $23-49$.

JUNTTILA, O., and NILSSEN, J. 1993. Growth and development of northern forest trees as affected by temperature and light. In: 
Alden, J., Mastrantonio, J.L., and Ødum, S., eds. Forest development in cold climates. NATO ASI Series. Series A: Life Sciences Vol. 244. 43-57.

JUNTTILA, O., and SKARET, G. 1990. Growth and survival of seedlings of various Picea species under northern climatic conditions. Scandinavian Journal of Forest Research 5:69-81.

KALLIO, P., LAINE, U., and MÄKINEN, Y. 1969. Vascular flora of Inari Lapland. 1. Introduction and Lycopodiaceae Polypodiaceae. Reports from the Kevo Subarctic Research Station 5:1-108.

KALLIO, P., HURME, H., EUROLA, S., NOROKORPI, Y., and SEPPONEN, P. 1986. Research activities on the forest line in northern Finland. Arctic 39(1):52-58.

KELLOMÄKI, S., HÄNNINEN, H., and KOLSTRÖM T. 1992. Model computations on the impacts of the climatic change on the productivity and silvicultural management of the forest ecosystem. Silva Fennica 22:293-305.

KELLOMÄKI, S., VÄISÄNEN, H., and KOLSTRÖM, T. 1997. Model computations on the effects of elevating temperature and atmospheric $\mathrm{CO}_{2}$ on the regeneration of Scots pine at the timber line in Finland. Climatic Change 37:683-708.

KJÄLLGREN, L., and KULLMAN, L. 1998. Spatial patterns and structure of the mountain birch tree-limit in the southern Swedish Scandes: A regional perspective. Geografiska Annaler 80 A(1): $1-15$.

KOLJONEN, T., GUSTAVSSON, N., NORAS, P., and TANSKANEN, H. 1992. The geochemical atlas of Finland, Part 2: Till. 218 p. +1 app.

KULLMAN, L. 1981. Recent tree-limit dynamics of Scots pine (Pinus sylvestris L.) in the southern Swedish Scandes. Wahlenbergia 8:1-67.

- 1991. Pattern and process of present tree-limits in the Tärna region, southern Swedish Lapland. Fennia 169(1):25 - 38.

___ 1992. Climatically induced regeneration patterns of marginal populations of Pinus sylvestris in northern Sweden. Oecologia Montana 1:5-10.

- 1996. Rise and demise of cold-climate Picea abies forest in Sweden. New Phytology 134:243-256.

. 1997. Tree-limit stress and disturbance: A 25-year survey of geoecological change in the Scandes mountains of Sweden. Geografiska Annaler 79 A(3):139-165.

. 2000. Tree-limit rise and recent warming: A geoecological case study from the Swedish Scandes. Norwegian Journal of Geography 54:49-59.

- 2001. 20th century climate warming and tree-limit rise in the southern Scandes of Sweden. Ambio 30:72-80.

KULLMAN, L., and HÖGBERG, N. 1989. Rapid natural decline of upper montane forests in the Swedish Scandes. Arctic 42: 217-226.

KULLMAN, L., and KJÄLLGREN, L. 2001. A coherent postglacial tree-limit chronology (Pinus sylvestris L.) for the Swedish Scandes: Aspects of paleoclimate and "recent warming," based on megafossil evidence. Arctic, Antarctic, and Alpine Research 32:419-428.

LEDIG, F.T., and KITZMILLER, J.H. 1992. Genetic strategies for reforestation in the face of global change. Forest Ecology and Management 50:153-169.
LEEMANS, R. 1995. Modelling global change impacts. In: Korpilahti, E., Salonen, T., and Oja, S., eds. Caring for the forest: research in a changing world. Abstracts of invited papers. IUFRO XX World Congress, 6-12 August 1995, Tampere, Finland. 127.

MÄKINEN, H., NÖJD, P., and MIELIKÄINEN, K. 2000. Climatic signal in annual growth variation of Norway spruce (Picea abies) along a transect from central Finland to the Arctic timberline. Canadian Journal of Forest Research 30:769-777.

NILSSON, U., and GEMMEL, P. 1993. Changes in growth and allocation of growth in young Pinus sylvestris and Picea abies due to competition. Scandinavian Journal of Forest Research 8:213-222.

OJANSUU, R., and HENTTONEN, H. 1983. Estimation of local values of monthly mean temperature, effective temperature sum and precipitation sum from the measurements made by the Finnish Meteorological Office. Silva Fennica 17:143-160. (In Finnish with English summary.)

PAYETTE, S., and FILION, L. 1984. White spruce expansion at the tree line and recent climatic change. Canadian Journal of Forest Research 15:241-251.

PERSSON, B., and BEUKER, E. 1997. Distinguishing between the effects of changes in temperature and light climate using provenance trials with Pinus sylvestris in Sweden. Canadian Journal of Forest Research 27:572-579.

POTVIN, C., LECHOWICZ, M., and TARDIF, S. 1990. The statistical analysis of ecophysiological response curves obtained from experiments involving repeated measures. Ecology 71:1389-1400.

RIKALA, R., and REPO, T. 1987. Frost resistance and frost damage in Pinus sylvestris seedlings during elongation. Scandinavian Journal of Forest Research 2:433-440.

RITARI, A. 1990. Temperature, snow and soil frost conditions in northern Finland during winter 1986-87. In: Kinnunen, K., and Varmola, M., eds. Effects of air pollutants and acidification in combination with climatic factors on forests, soils and waters in northern Fennoscandia. Report from a Workshop, 17-19 October 1988, Rovaniemi, Finland. Nordic Council of Ministers. North 1990 (20):44-52.

RITCHIE, J.C. 1986. Climate change and vegetation response. Vegetatio 67:65-74.

RYYNÄNEN, M. 1982. Individual variation in seed maturation in marginal populations of Scots pine. Silva Fennica 16:185-187.

SARVAS, R. 1962. Investigations on the flowering and seed crop of Pinus sylvestris. Communicationes Instituti Forestalis Fenniae 53. $198 \mathrm{p}$.

. 1970. Investigation on the flowering and seed crop of Picea abies. Communicationes Instituti Forestalis Fenniae 67. $84 \mathrm{p}$.

SIRÉN, G. 1993. Advances and retreats of pine tree and timber lines in the far north of Finland. World Resource Review Vol. 5(1): $104-110$.

SOKAL, R.R., and ROHLF, F.J. 1981. Biometry. San Francisco: Freeman.

SOLANTIE, R. 2000. Snow depth on January 15 th and March 15 th in Finland 1919-98, and its implications for soil frost and forest ecology. Finnish Meteorological Institute: Meteorological Publications No. 42. 176 p. 
STOCKS, B.J., FOSBERG, M.A., LYNHAM, T.J., MEARNS, L., WOTTON, B.M., YANG, Q., JIN, J.Z., LAWRENCE, K., HARTLEY, G.R., MASON, J.A., and McKENNEY, D.W. 1998. Climate change and forest fire potential in Russian and Canadian boreal forests. Climatic Change 38(1):1-13.

STÖCKLIN, J., and KÖRNER, C. 1999. Recruitment and mortality of Pinus sylvestris near the nordic tree line: The role of climatic change and herbivory. Ecological Bulletins 47:168-177.

SUTINEN, M.-L., RITARI, A., HOLAPPA, T., and KUJALA, K. 1998. Seasonal changes in soil temperature and in the frost hardiness of Scots pine (Pinus sylvestris) roots under subarctic conditions. Canadian Journal of Forest Research 28:946-950.
THAM, A. 1989. Prediction of individual tree growth in managed stands of mixed Norway spruce (Picea abies (L.) Karst.) and birch (Betula pendula Roth \& B. pubescens Ehrh.). Scandinavian Journal of Forest Research 4:491-512.

TUHKANEN, S. 1980. Climatic parameters and indices in plant geography. Acta Phytogeographica Suecica 67:1-110.

. 1984. A circumboreal system of climatic-phytogeographical regions. Acta Botanica Fennica 127:1-50 + 2 app.

TUOMISTO, H., and NEUVONEN, S. 1993. How to quantify differences in epicuticular wax morphology of Picea abies (L.) Karst. needles. The New Phytologist 123:787-799.

ZAR, J.H. 1984. Biostatistical analysis. Englewood Cliffs, New Jersey: Prentice-Hall, Inc. 